\title{
Biology and Treatment of Skeletal Manifestations in Multiple Myeloma
}

\author{
Nikolaos A. Stavropoulos, ${ }^{1,2}$, Argyro Papadoyiannis', Dimitris Maltezas, \\ Petros Stavrou ${ }^{4}$, George C. Babis 5 , Panayiotis J. Papagelopoulos ${ }^{2}$, \\ Gerasimos A. Pangalis ${ }^{6}$, Marie-Christine Kyrtsonis ${ }^{1}$ \\ ${ }^{1}$ Hematology Section of First Department of Propedeutic Internal Medicine, National and Kapodistrian \\ University of Medicine, Laikon University Hospital, Athens, Greece \\ ${ }^{2} 1$ st Department of Orthopaedics, Attikon University General Hospital, University of Athens Medical School, \\ Haidari, Athens, Greece \\ ${ }^{3}$ Section of Internal Medicine, General Hospital of Lakonia, Sparti, Greece \\ ${ }^{4}$ Spine Clinic, American Medical Center, Nicosia, Cyprus \\ ${ }^{5} 2$ nd Department of Orthopaedics, Konstantopouleio General Hospital N. Ionia, University of Athens Medical \\ School, N. Ionia, Athens, Greece \\ ${ }^{6}$ Hematology Clinic, Athens Medical Center, Psychiko Branch, Psychiko, Athens, Greece \\ Email: mck@ath.forthnet.gr
}

Received 22 January 2014; revised 20 February 2014; accepted 27 February 2014

Copyright ( 2014 by authors and Scientific Research Publishing Inc.

This work is licensed under the Creative Commons Attribution International License (CC BY).

http://creativecommons.org/licenses/by/4.0/

(c) (i) Open Access

\begin{abstract}
MM is frequently associated with the development of osteolytic bone lesions, osteoporosis and pathological fractures. Bone destruction in MM is caused by osteoclasts recruited in areas adjacent to myeloma plasma cells; their contact triggers both cell types to secrete soluble factors sustaining one each other's activation and proliferation. Osteoclasts differentiate and maturate upon binding of the receptor activator of NF-kappaB ligand (RANKL), secreted by bone marrow microenvironmental cells, to its receptor (RANK) on osteoclast progenitors, while osteoprotegerin (OPG), a natural decoy receptor, can block the aforementioned ligation. At the same time osteoblasts are inactivated by the Wnt/ $\beta$-catenin signaling pathway inhibitor, Dickkopf-1 protein (DKK-1), secreted by malignant plasma cells. Furthermore, DKK-1 deregulates the OPG/RANKL equilibrium, promoting osteoclastogenesis. Myeloma bone disease (MBD) can be treated with myeloma-directed chemotherapy and agents inhibiting bone resorption such as aminobisphosphonates, although new promising biology driven monoclonal antibodies targeting osteoclastogenesis mechanisms are emerging. Palliative MBD treatment includes analgesics, orthotics, radiation therapy, vertebroplasty and kyphoplasty. In case of spinal cord compression, radiation therapy or surgical decompression, should be instantly performed, along with steroid administration. Surgery may also be an option especially in case of weight-bearing bone fractures. MBD is a morbid complication and should be carefully managed because it deteriorates patients' quality of life and worsens dis-
\end{abstract}


ease outcome.

\section{Keywords}

\section{Multiple Myeloma, Skeletal Manifestations, Biology, Treatment}

\section{Introduction}

Multiple myeloma (MM) is a relatively frequent hematological neoplasm that is characterized by bone marrow (BM) infiltration by malignant plasma cells secreting a monoclonal component in the serum or urine. Disease symptomatology includes a wide range of manifestations among whose skeletal ones are the most frequent concerning about $80 \%$ of newly diagnosed symptomatic patients [1]. Therefore, bony signs are included in the CRAB criteria for the recognition of symptomatic patients in need of immediate treatment. The aforementioned criteria comprise hypercalcemia (C), renal complications (R), anemia (A) and bone disease (B) [2]. Patients' median survival is of about $4-5$ years with increasing evidence of outcome improvement with the systematic use of new drugs [3]. Significant morbidity may be observed during disease course, partly due to bone pains although considerable progresses have been made in skeletal supportive care.

Bone disease underlying pathophysiology is intrinsically related to MM biology itself and the better understanding of both has leaded to new potent therapeutic modalities.

In the present context, our purpose is to describe the biologic background and the therapeutic state of the art in relation with MM skeletal manifestations and to present, in addition, some relevant results from our group.

\subsection{Myeloma Related Skeletal Manifestations}

Approximately $60 \%$ of symptomatic MM patients suffer from bone pains [4]. Although clinical manifestations of MM are variable, spontaneous fractures, osteoporosis and spinal cord roots compression symptoms are additional clinical findings at diagnosis and throughout disease course that lead to increased morbidity [1] [5]. Lytic lesions, related to osteoclast activation induced by a network of cytokines, are a hallmark of MM [6]. The development of bone destruction is a catastrophic complication for most patients with malignancies and among cancers or hematologic malignancies, MM is the first cause of bone involvement; likewise, Saad et al. evaluated over a 21 months period a series of 3049 patients suffering from malignancy-related bone disease, and showed that the highest incidence of spontaneous fracture (43\%) was observed in MM patients, as compared to breast, prostate and lung cancer [7].

Bone destruction in MM can involve any bone [6], most likely the spine (49\%), skull (35\%), pelvis (34\%), ribs (33\%), humerus (22\%) and femur (13\%) as shown in Figure 1. The pelvis and proximal femur are common sites of solitary plasmatocytoma [5].

Bone plasmacytomas are plasma cell masses arising from bones; they may affect the blood supply of the spinal cord, the vertebras' columns, the meninges or the nerve roots, thus leading to sensation defect, muscle weakness and dysfunction or even loss of bladder of bowel sphincter control. These emergency issues require immediate management in order to avoid paralysis [6] [8].

According to guidelines, myeloma bone disease (MBD) is assessed by skeletal x-rays of the skull, chest, spine, pelvis, humeri, and femora, although conventional radiographic findings are not sensitive enough to reveal small lesions and efforts are made to improve MBD routine imagine. Nevertheless, about $80 \%$ of MM patients present at diagnosis, some kind of MBD, as assessed by x-rays, including diffuse osteoporosis, multiple lytic lesions and $25 \%$ spontaneous fractures. Death risk is increased by more than $20 \%$ in MM patients with fractures. Moreover Durie and Salmon included conventional radiographs' findings in their staging; they built a bone scale and patients were scored 0 when no lesions were seen, 1 in the presence of diffuse osteoporosis and up to 1 osteolysis, 2 with multiple osteolyses and 3 when extensive lytic changes with pathologic fractures were observed. Scale 4 patients were automatically staged III [9].

In a study on $260 \mathrm{MM}$ patients, with a median survival of 38 months, skeletal lytic changes strongly correlated with time to treatment but showed only a trend for decreased survival in patients with Durie and Salmon bone scale 3 - 4 [10]. We examined the same in a series of 177 consecutive MM patients and found that those 


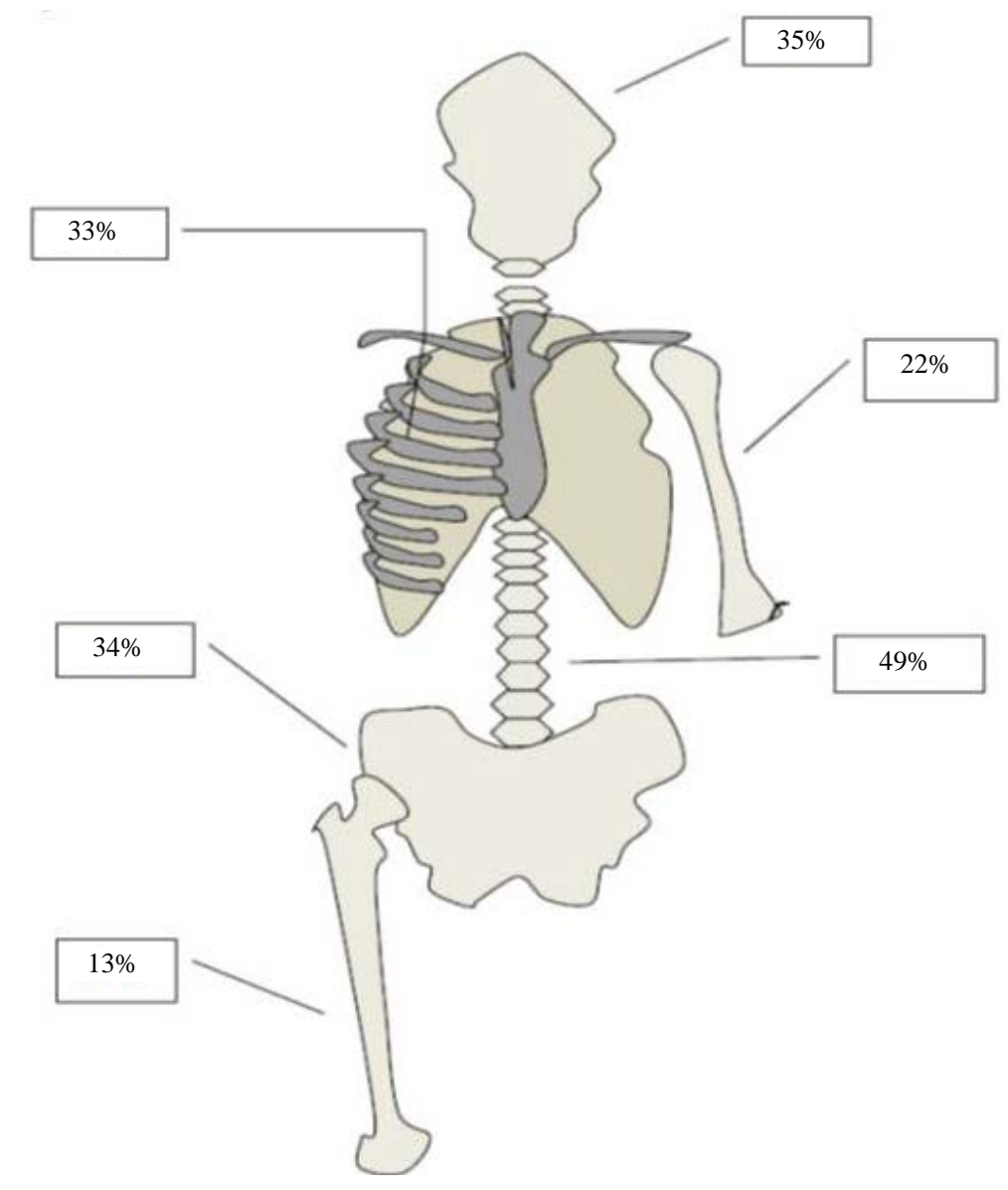

Figure 1. Skeletal distribution of multiple myeloma.

suffering from spontaneous fractures at diagnosis, representing the $24 \%$, faced a worse outcome with an median overall survival of 30 months compared to 86 months $(\mathrm{p}<0.00001)$ (Figure 2).

\subsection{Underlying Biology}

In the bone marrow of MM patients, a continuous interplay between malignant plasma cells and microenvironmental cells, lead to cytokine production, mediators' expression and signaling pathways activation, thus contributing to plasma cells proliferation, expansion and disease evolution. An important process that takes place within the medullar environment includes the interactions between plasma cells and osteoclasts (OC). Osteoclasts are the primary bone-resorbing cells in both normal and neoplastic states. Bone destruction in MM is caused by OC proliferating in bony areas adjacent to myeloma cells. Both MM and OC cells secrete soluble factors that sustain each other's activity [11] [12]. Cytokines involved in osteoblasts and osteoclasts regulation are presented in Table 1, while their main biological actions and clinical consequences are described below.

\subsubsection{OPG/RANKL}

Proliferation, differentiation and apoptosis of OC are normally regulated by members of the tumor necrosis factor family of receptors and ligands [13]. The receptor of NF-kB ligand (RANKL) expressed on the surface of BM stromal cells, binds to its receptor RANK expressed on OC precursors, leading to osteoclast formation and activation [14] [15]. This process can be inhibited by osteoprotegerin (OPG), a soluble decoy receptor, that interferes between RANK and RANKL bounding, thus inhibiting OC development [12] [15] [16]. The expression of RANKL and OPG is normally controlled by hormones, growth factors and cytokines [17]. In MM, malignant cells themselves were found to express RANKL and furthermore to trigger RANKL expression by other cells; furthermore, myeloma cells were shown to decrease OPG concentrations in the local environment, possibly by 


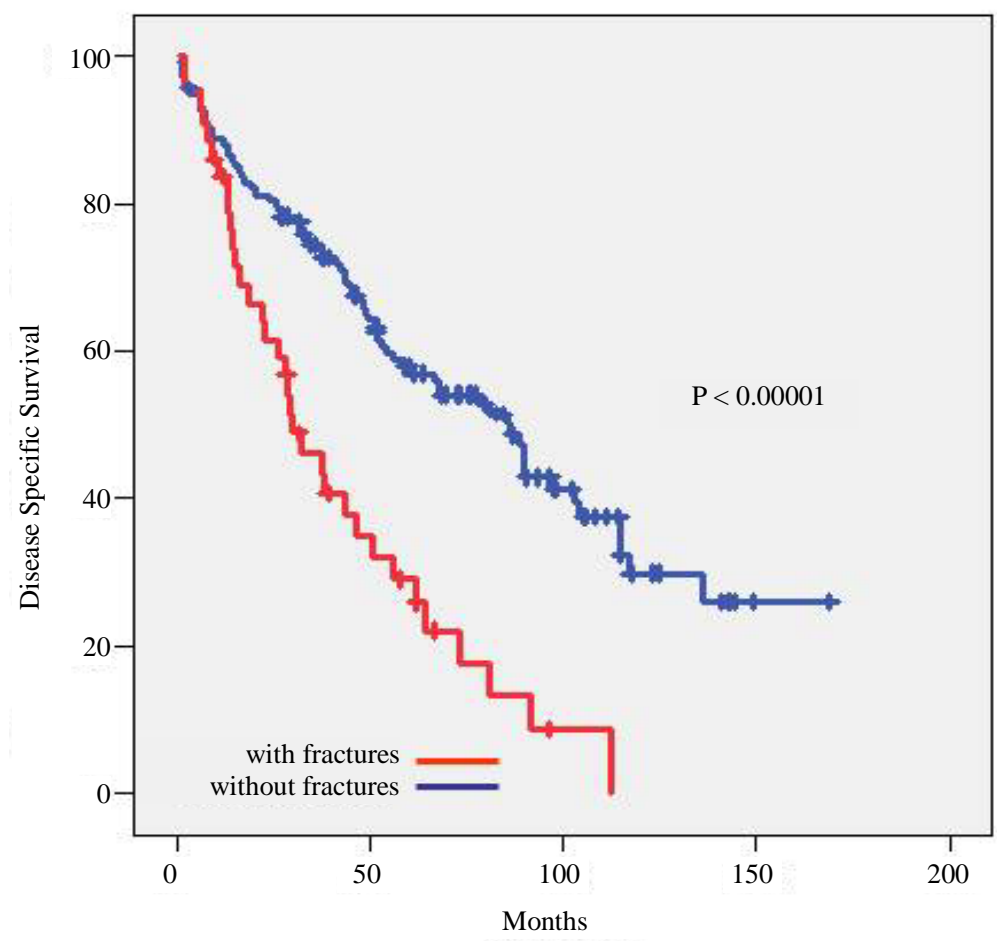

Figure 2. Disease specific survival. Life expectancy in patients with and without fracture.

Table 1. Cytokines involved in osteoblasts and osteoblasts regulation.

\begin{tabular}{|c|c|c|c|c|}
\hline \multirow{2}{*}{ Cytokine } & \multicolumn{2}{|c|}{ Osteoblasts } & \multicolumn{2}{|c|}{ Osteoclasts } \\
\hline & Upregulation & Downregulation & Upregulation & Downregulation \\
\hline RANKL & & & & $\sqrt{ }$ \\
\hline OPG & $\sqrt{ }$ & & & \\
\hline TGF-b & & & & $\sqrt{ }$ \\
\hline PDGF & & & & $\sqrt{ }$ \\
\hline IGF I, II & & & & $\sqrt{ }$ \\
\hline BMPs & $\sqrt{ }$ & & & $\sqrt{ }$ \\
\hline TNF-a & & & $\sqrt{ }$ & \\
\hline IL-1 & & & $\sqrt{ }$ & \\
\hline IL-3 & & $\sqrt{ }$ & & \\
\hline IL-6 & & & $\sqrt{ }$ & \\
\hline MIP-1a & & & $\sqrt{ }$ & \\
\hline DKK-1 & & $\sqrt{ }$ & & \\
\hline VEGF & & & $\sqrt{ }$ & \\
\hline b FGF & & & $\sqrt{ }$ & \\
\hline
\end{tabular}

its internalization and degradation [18]. In addition, some groups reported that serum OPG levels in MM patients were inversely associated with bone disease and were decreased as compared to normal individuals [19]; 
on the contrary serum soluble RANKL was found elevated in MM, while the soluble RANKL/OPG ratio was increased and correlated with bone disease and overall survival [20]. Other groups however, including ours, found higher serum OPG levels in MM patients as compared to healthy individual [20]-[29] while in addition, serum OPG correlated with adverse prognostic markers such as increased beta2-microglobulin. Published diverging results on serum OPG levels are shown in Table 2. Recombinant OPG is effective in suppressing bone resorption in postmenopausal women [30], but the initial enthusiasm to administrate it in patients with MM [31] was abandoned and scientific community interest turned toward monoclonal antibodies against RANKL. Denosumab is a human monoclonal IgG $_{2}$ antibody that selectively binds to RANKL and is currently tested in MM patients for the prevention of bone destruction; results are encouraging and it was shown to produce a more rapid decline in bone turnover markers within 12 hours of injection compared to aminobisphosphonates, that are for the time being the standard of care for MBD [32].

\subsubsection{Dickkopf-1}

Dkk-1 (Dickkopf-1) protein is a natural inhibitor of Wnt/ $\beta$-catenin signaling pathway that is responsible for the differentiation of osteoblast precursors. Bone cells homeostasis is regulated by Wnts, a family of 19 glycoproteins that up-regulate intracellular pathways resulting in $\beta$-catenin accumulation that along with the activation of other regulators lead to the expression of osteoblastic genes [33]. Dkk-1 secreted by myeloma cells contributes to increased osteoclastogenesis by changing the ratio of OPG and RANK [33] [34]. Increased levels of Dkk-1 inhibit activation of the Wnt3a protein, resulting in reduced OPG expression and increased RANKL one, thus exacerbating osteoclastogenesis. High serum levels of Dkk-1 were associated with the presence of lytic bone lesions in MM patients in a study by Tian et al. who compared $45 \mathrm{MM}$ patients with no bone lesions, as detected by MRI, to 137 with detectable lesions [35]. However, there was no correlation between Dkk-1 levels and severity of symptoms or disease activity [35]. Transgenic mice overexpressing Dkk-1, exhibit osteopenia,

Table 2. Published diverging results on serum OPG levels.

\begin{tabular}{|c|c|c|c|}
\hline Author & \#Pts studied & Pts status & Correlations found and/or comments \\
\hline $\begin{array}{l}\text { Goranova-Marinova } \\
\text { (2007) [21] }\end{array}$ & 66 & At diagnosis & $\begin{array}{l}\text { 1. OPG levels higher in } \mathrm{MM} \text { compared to } \mathrm{HI} \\
\text { 2. The OPG/creatinin ratio eliminated the difference } \\
\text { 3. OPG levels correlared with } \mathrm{b}_{2} \mathrm{M} \text { and reversely with } \mathrm{MBD}^{*}\end{array}$ \\
\hline Martini (2006) [22] & 26 & $\begin{array}{l}\text { At diagnosis } \\
\text { (smoldering myeloma) }\end{array}$ & OPG levels lower in MM compared to HI \\
\hline Terpos (2005) [23] & 35 & $\begin{array}{l}\text { Refractory ( } 7) \text { or } \\
\text { relapsed (28) myeloma }\end{array}$ & $\begin{array}{l}\text { 1. OPG levels higher in MM before treatment compared to HI } \\
\text { 2. The OPG/creatinin ratio eliminated the difference }\end{array}$ \\
\hline Kraj (2005) [24] & 133 & & $\begin{array}{l}\text { 1. OPG levels higher in MM compared to } \mathrm{HI} \\
\text { 2. OPG levels higher in pts with renal failure and hypercalcemia } \\
\text { 3. OPG levels correlated with age, } \mathrm{b}_{2} \mathrm{M} \text { and bone marrow OPG } \\
\text { concentrations }\end{array}$ \\
\hline Depil (2005) [25] & 140 & $\begin{array}{l}\text { At diagnosis } \\
39 \text { asymptomatic } \\
101 \text { mptomatic }\end{array}$ & $\begin{array}{l}\text { 1. OPG levels higher in MM compared to } \mathrm{HI} \\
\text { 2. No statistically significant difference between symptomatic and } \\
\text { asymptomatic } \mathrm{MM} \text { pts } \\
\text { 3. OPG levels correlated with } \mathrm{b}_{2} \mathrm{M} \text { and creatinine } \\
\text { 4. High OPG levels associated with a poorer survival }\end{array}$ \\
\hline Corso (2004) [26] & 103 & $\begin{array}{l}39 \text { at diagnosis } \\
64 \text { treated }\end{array}$ & OPG higher in MM and MGUS compared to HI. \\
\hline Kyrtsonis (2004) [27] & 32 & $\begin{array}{l}27 \text { at diagnosis } \\
5 \text { at remission }\end{array}$ & $\begin{array}{l}\text { 1. OPG levels higher in MM compared to } \mathrm{HI} \\
\text { OPG levels correlated with } \mathrm{b}_{2} \mathrm{M}\end{array}$ \\
\hline Terpos (2004) [28] & 51 & $\begin{array}{l}4 \text { at } \mathrm{CR}, 44 \text { at } \mathrm{PR} \\
3 \text { progressive/resistant }\end{array}$ & OPG levels lower in MM pre-ASCT compared to HI \\
\hline Terpos (2003) [20] & 121 & At diagnosis & $\begin{array}{l}\text { 1. OPG levels lower in MM compared to HI } \\
\text { 2. OPG levels correlared with } \mathrm{b}_{2} \mathrm{M} \text {, CRP and IL- } 6 \text { levels, and inversely } \\
\text { with MBD and serum markers of bone resorption }\end{array}$ \\
\hline Seidel (2001) [29] & 225 & At diagnosis & $\begin{array}{l}\text { 1. OPG levels lower in MM compared to HI } \\
\text { 2. OPG levels correlated with serum markers of bone formation and } \\
\text { inversely with MBD and performance status }\end{array}$ \\
\hline
\end{tabular}


while reduced levels are accompanied by increased bone mass [36] [37]. Dkk-1 serum concentrations were also found to correlate with ISS staging in 50 patients, 32 at diagnosis and 18 pre- and post-autologous stem cell transplantation (ASCT) [38] and with the extent of MBD [39]. In our experience [40], serum DKK1 strongly correlated with the presence of spontaneous bone fractures, as shown in Figure 3(a) and Figure 3(b). We had determined serum DKK1 by ELISA (human DKK-1, Duoset, R \& D Systems) in 75 MM patients at diagnosis, including 11, 21, 21 and 22 patients with Durie and Salmon bone scale 0, 1, 2 and 3 respectively. No statistical difference was observed between serum DKK1 levels in 14 healthy individuals and patients bone scaled 0 to 2, neither was serum DKK1 concentrations related to parameters of disease activity or with survival.

\subsubsection{Macrophage Inflammatory Proteins}

Macrophage inflammatory protein 1a and 1b (MIP-1a, MIP-1b) are osteoclastogenesis inducing chemokines that participate in the pathogenesis of osteolytic lesions [41]. Albeight the ambiguous findings showing a role of MIP-1a on myeloma cells survival and growth [42] [43], its critical role on MBD is crearly outlined. MIP-1a promotes osteoclastogenesis and bone resorption either directly by acting on pre-osteoclasts or indirectly enhancing the activity of RANKL on osteoclasts and the activity of IL-6 [44]-[47]. High serum MIP-1a levels in MM patients were assosiated with extensive bone disease and degreased life expectancy ( $<3$ years) [48]. However, the positive correlation between MIP- $1 \alpha$ and $\beta 2$-microglobulin in MM patients at diagnosis further supports

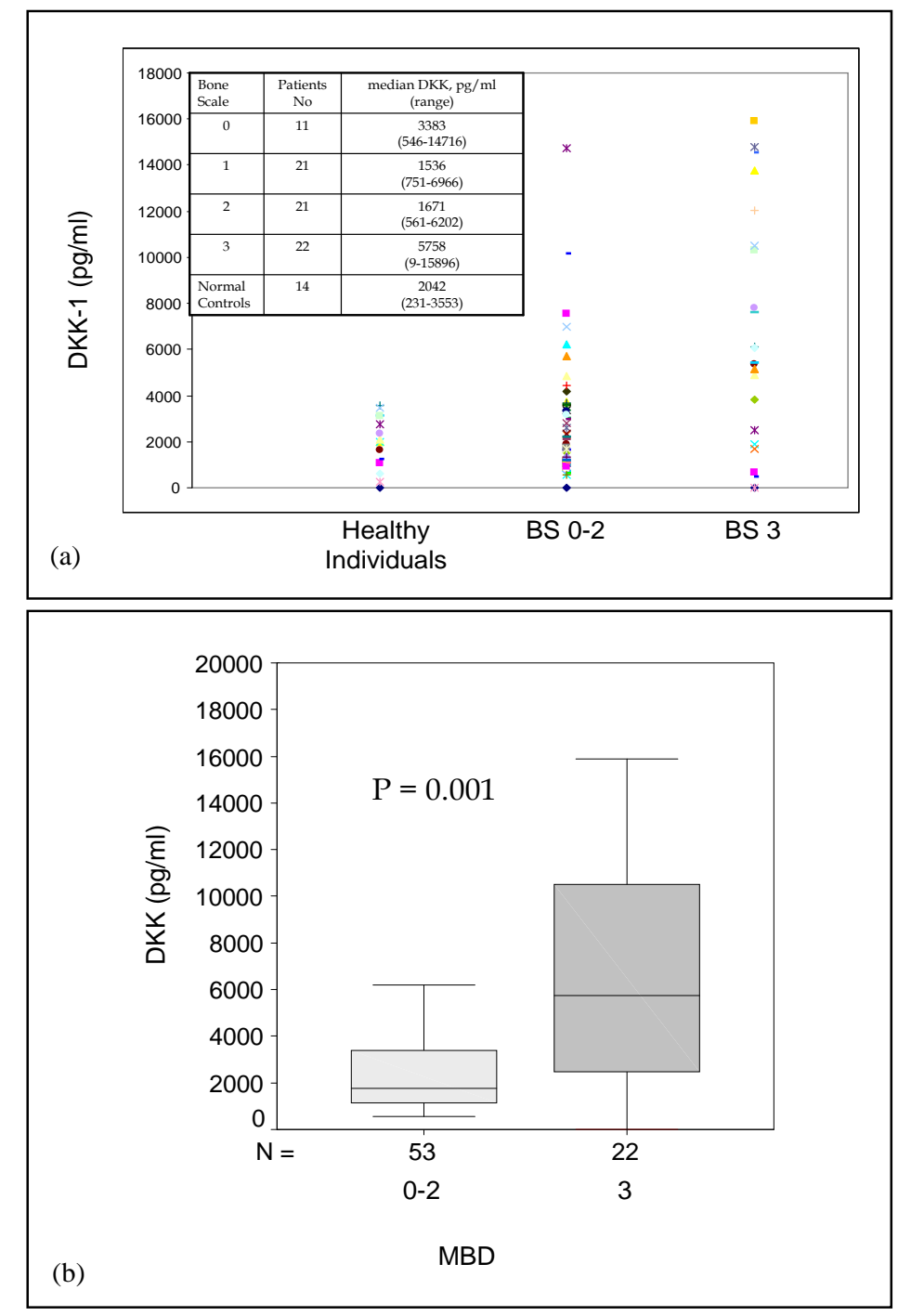

Figure 3. Correlations of serum Dkk-1 levels with myeloma bone disease. 
the idea that MIP-1 $\alpha$ is not only a chemokine involved in bone resoption but is also tangled in myeloma cell growth and survival [49]. In aggreement with the last, we also found that serum MIP- $1 \alpha$ determined in 82 MM patients at diagnosis by ELISA (Quantikine, Human MIP-1a, R\&D Systems, Minneapolis, USA), was related to markers of disease activity. Likewise, it mainly correlated with beta2-microglobulin (Spearman's rho $0.45, \mathrm{p}=$ 0.0002 ) and consequently with ISS stages; MIP-1a levels were $28.3 \pm 11.3$ in ISS stage 1, $29.8 \pm 11.1$ in ISS stage 2, $39 \pm 19.2$ in ISS stage 3 ( $p=0.02$ ) [50]. With regard to MBD, MIP serum levels were lower in patients scaled 0 - 1 according to Durie and Salmon's bone scale in comparision of those scaled 2 - 3 with corresponding mean concentrations of 45.59 versus $65.03 \mathrm{pg} / \mathrm{ml}(\mathrm{p}=0.01)$.

\subsubsection{Insulin Growth Factor-1 (IGF -1)}

IGF-1, produced by bone marrow stromal cells and osteoblasts, contributes to myeloma cell survival [51]-[56]. IGF-1 and its receptor are preferentially expressed by MM cells [57] as compared to B-lymphoblastoid cell lines. IGF-1 serves as a chemoattractant for neoplastic plasma cells cells [51]. It augments the proliferative and antiapoptotic effects of IL-6 [58] [59] and may have an equally important proliferative and anti-apoptotic effect as IL-6 on myeloma cells [60]-[62]. It was furthermore shown to be a strong indicator of prognosis in MM patients [63]. Interestingly, IGF-1 may contributes to the correlation of obesity and diabetes to neoplasia [64]. Because IGF-1 was involved in eventual down-regulation of osteoclasts, we investigated in $61 \mathrm{MM}$ patients, studied at diagnosis, wether its serum levels correlated with MBD but no statistical significant relationship was found.

\subsubsection{Other Cytikines Implicated in MBD}

Osteoclasts are further regulated in MM by numerous osteoclast-activating factors (OAF) that include TNF- $\alpha$, IL-1, IL-6 and other soluble molecules. In addition because cell to cell contact between OC and plasma cells activates both cell types, any factor that sustains myeloma cell survival and proliferation, including endothelial cell mitogens, will indirectly promote MBD. The report of all these factors, in the present context would be fastidious to the reader and will be skipped.

\subsection{Treatment}

Treatment of skeletal manifestations in MM requires management of the underlying malignancy but improvement of bone pains with chemotherapy may be delayed for one or two months and may be unbearable; so palliative analgesia may be required. In addition, the risk of spontaneous fracture significantly increases around the time of diagnosis [64], and adjuvant inhibition of bone resorption with aminobisphosphonates or eventually newly manufactured monoclonal antibodies is mandatory. Furthermore, in case a spontaneous fracture has already happened, at the time of diagnosis (or afterward), or that spinal cord compression symptoms occur, emergency treatment is needed in order to avoid devastating complications. Therefore MBD treatment can be subdivided into palliative, adjuvant and emergency therapy, indeed without omitting underlying MM treatment.

\subsubsection{Myeloma Treatment}

Because of the close relationship between myeloma plasma cells and osteoclasts, any treatment that will control and decrease plasma cell proliferation will also lead to decreased osteoclast activity and subsequently of MBD improvement.

Myeloma therapy has consistently improved over the last years. According to patient's age and disease aggressiveness, induction treatment upon diagnosis of symptomatic disease can include a combination of alkyliating agents (melphalan or cyclophosphamide), new agents, eventually anthracyclins and almost always corticosteroids; then after response, high dose treatment with autologous stem cell transplantation should be offered to younger patients. The so called new agents (thalidomide, lenalidomide, bortezomib and the new generation of ImiDs and proteasome inhibitors), introduced in the past 2 decades, have revolutionized myeloma therapeutics and resulted in improved outcomes [65] [66] and complete remission rates that were never observed before. Among these drugs, bortezomib has an osteoblast activating effect as it normalizes indices of bone remodeling, increases bone-type alkaline phosphatase and reduces serum dickkopf-1 [67]. Lenalidomide also was shown to reduce bone resorption in responding patients with relapsed/refractory multiple myeloma [68]. However, it should not be forgotten that these agents are administrated in combination with dexamethasone, the long term ingestion of which may increase osteoporosis. 


\subsubsection{MBD Palliative Treatment}

Palliation of pain is a significant issue to deal with as it has serious impact on patient's quality of life. Therefore, proper use of analgesia is needed. Steroids procure an immediate relief of pain. Light narcotics may be of help until pain is controlled by chemotherapy or radiation. Nonsteroidal anti-inflammatory Drugs (NSAID) should always be prescribed with caution, as they may exacerbate myeloma related renal injury. Moreover, the temporary use of back braces or spinal orthotics to stabilize the spine or the thoracic cage, provide a short term relief of pain as axial pain is a common and annoying clinical finding reflecting not only loss of structural integrity but an impending spontaneous fracture too. Additionally, orthotics may be rather helpful in the early stages of remobilization after treatment. Typically, orthotics should not be used for a long period as their use is supplementary.

Radiation Therapy can be considered for palliative treatment [69]. Pain relief is often achieved within one or two fractions of 3 - 4.0 Gy [69] [70]. Radiotherapy should be recommended as a primary treatment for peripatetic patients with no risks of impending spinal fracture [71]. If possible, radiation therapy should be avoided in bone marrow producing areas before stem cell collection, in candidates for high dose treatment and autologous stem cell transplantation.

Other palliative techniques for myeloma-related spine pains are vertebroplasty and kyphoplasty. The aforementioned procedures are techniques indicated for low energy vertebral fractures either due to diffuse osteoporosis or to extensive osteolytic lesions. Vertebroplasty is the technique in which bone cement is injected percutaneously, under fluoroscopy, into the fractured vertebral body [72]. Balloon kyphoplasty may be considered as a modification of vertebroplasty; it requires the use of an expansible balloon into the vertebral body restoring that way its height [72]. The theoretical advantages of kyphoplasty over vertebroplasty are the ability to correct the kyphotic angle deformity and the reduced risk of adverse events such as cement leakage. The two techniques achieve pain relief in about $90 \%$ of patients [73]-[75]. Rare complications include inflammation, epidural hematoma, rib fractures, cement leakage, pulmonary embolism and systemic toxicity. Absolute contraindications involve bleeding disorders, infection, any contraindication to anesthesia, cord compression, severe cardiopulmonary insufficiency while relative ones include lesions above the level of T3, osteoblastic type of lesions, age below 40 years old, and fractures with obstructing and retropulsed bone [72] [76].

Kyphoplasty was included in the International Myeloma Working Group indications for painful vertebral compression fraction (more than $7 / 10$ on visual analog scale), in patients with significant loss of vertebral height and prolonged life expectancy [76].

Seventeen patients followed and treated in our section, with a total of 43 vertebral fractures or significant osteolytic lesions were treated with kyphoplasty. Through minimal incisions, two special inflatable balloons were transpedicularly or extrapedicularly inserted and inflated in each treated vertebrae. After appropriate inflation of the balloons a certain degree of reposition of the Vertebral Compression Fracture (VCF) was obtained. Consequently a proper amount of polymethylmethacrylat cement was injected in every vertebra. Deformity correction was evaluated using standard calculation formula based on the fractured vertical height pre and post operatively. Pain degree was estimated before and after the procedure using the VAS score. All 17 patients tolerated the procedure well; they were discharged ambulatory the following morning of the procedure. In $23 \%$ of the VCFs, the deformity correction achieved $90 \%$ of the vertebral body height restoration, in $61 \%$ resulted to $60 \%-89 \%$ restoration and for rest, the reduction was measured as 30\% - 59\%. Six months later the correction was stable. For a median follow up time of 18 months (range 4 - 30) there were no early or late complications related to the technique as cement extravasations, relapse of the MM in the same VB or even refracture. All patients experienced immediate and stable pain relief (median VAS pro-post: 6 - 1) and improvement in the quality of life (Figure 4).

Harrington in 1986 and later Mirel proposed scoring systems for decision making in impending pathologic fractures [77] [78]. Hip and periacetabular lesions, impending or pathological fractures of the acetabulum and long-bone fractures or any extensive skeletal destruction that may cause decreased quality of life, with increased pain and limitations in function and mobility, should be considered for surgical procedure [79] [80]-[82]. Prosthetic replacement is suggested for extensive hip lesions, pre operative radiation and total hip arthroplasty with acetabular reconstruction with or without reinforcement, depending on the extend of lesion, are suggested too (Figure 5); intramedullary devices over plates for lesions in the sub-trochanteric region [77]. Proximal femoral replacement should be considered in selected cases [77]. 

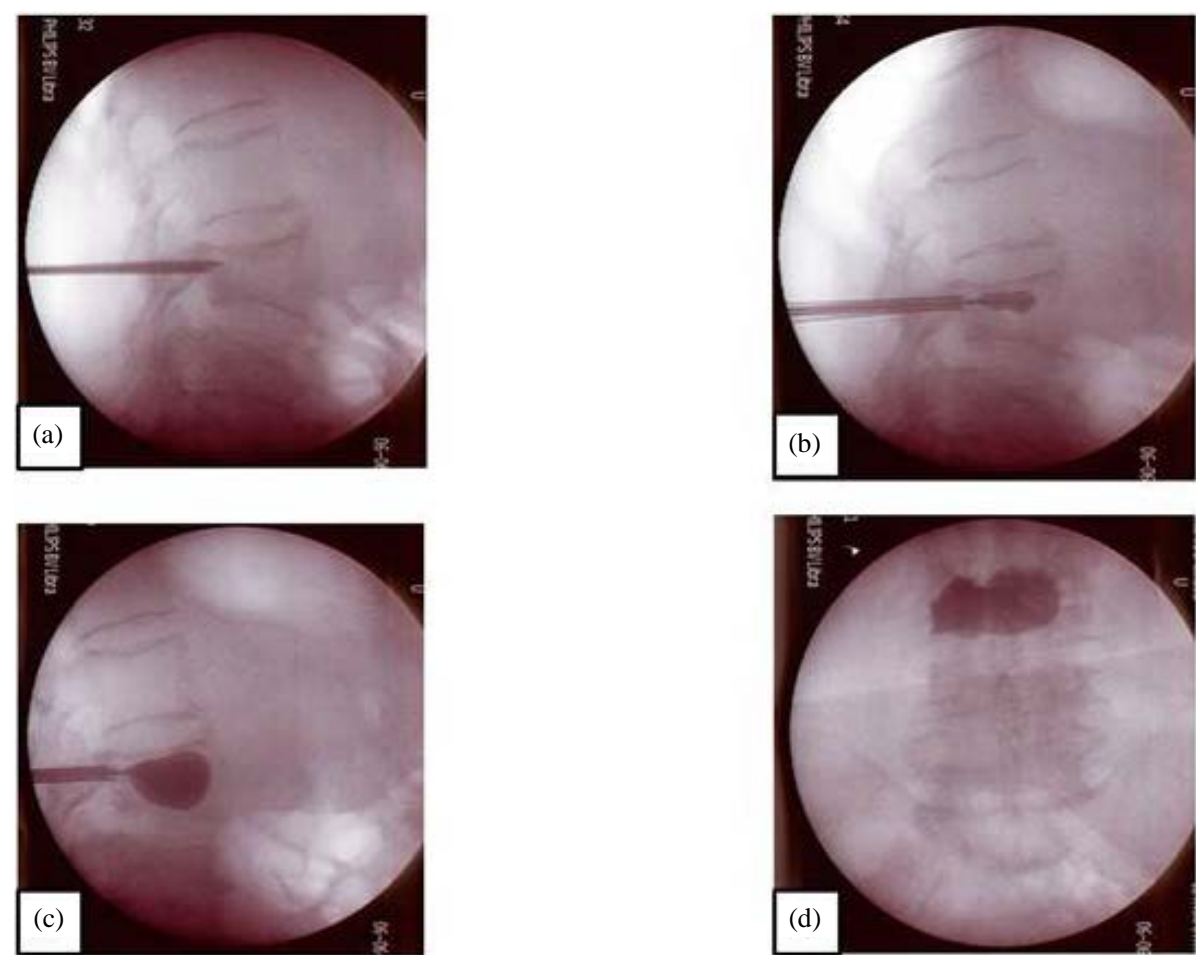

Figure 4. Ballon kyphoplasty. (a) Insert instrument in the fractured vertebra body; (b) Insert balloon Tamp; (c) Inflamation of the ballon and cement injection; (d) AP view just postoperatively.
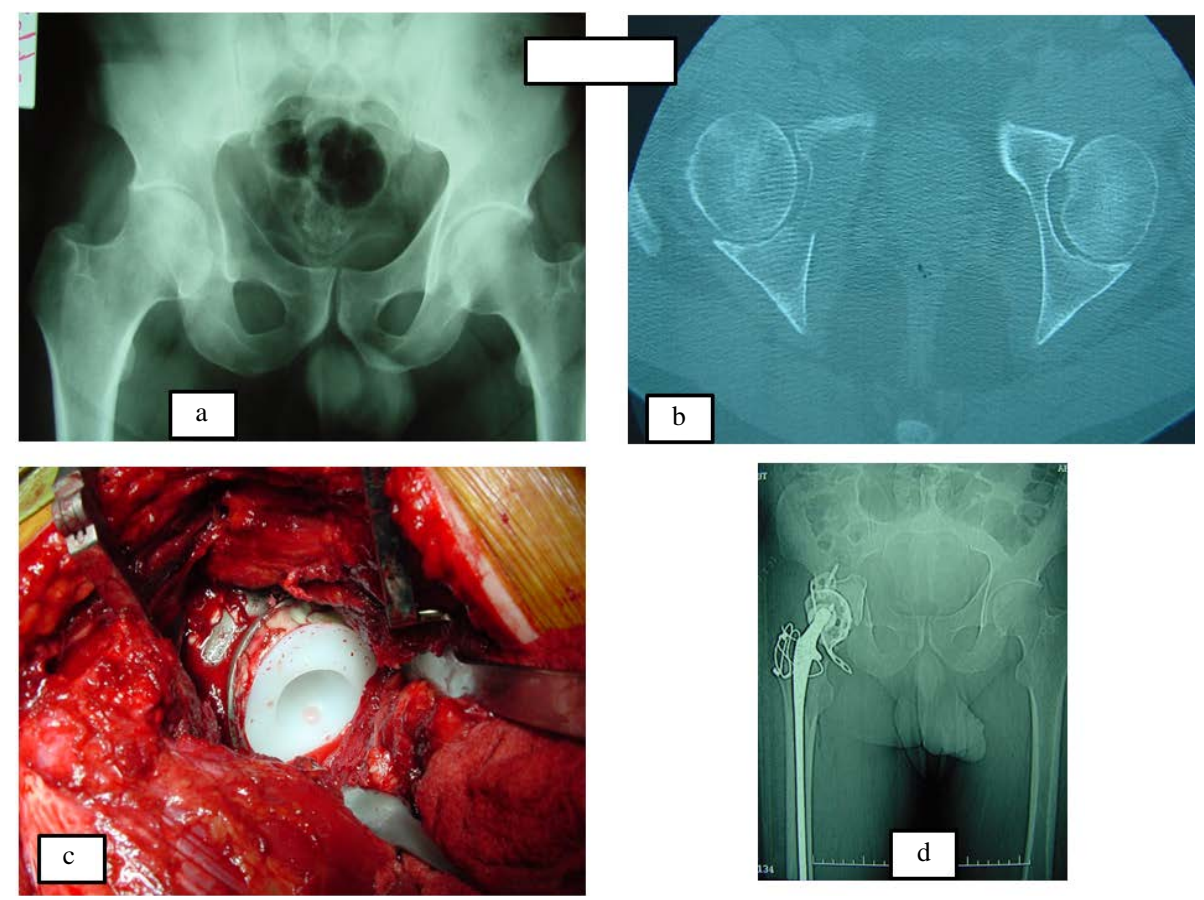

Figure 5. Anteroposterior radiographs of the hips of a 44-year-old man with multiple myeloma. (a) Class II lesion of the right acetabulum; (b) CT scan view of the lesion; (c) Right total hip arthroplasty with reconstruction of the acetabulum using an antiprotrusio cage, methylmethacrylate and screws fixed into the ilium; (d) The patient had a satisfactory result. Anteroposterior radiograph at 6 months follow up. 


\subsubsection{Inhibition of Bone Resorption}

In current practice, aminobisphosphonates (pamidronate or zolendronic acid) are administrated in almost all symptomatic MM patients with an acceptable renal function, concomitantly to chemotherapy, in order to prevent skeletal related manifestations.

Biphosphonates (BPs) are inhibitors of osteoclast-mediated bone resoption. Moreover, nitrogen-containing BPs suspend the osteoclastogenic signaling pathway [83]. They are also used for the management of diseaserelated hypercalcemia. They may have an additional antitumor activity including effects on MM cells proliferation, apoptosis and adhesion [84]-[89] immunomodulatory and anti-angiogenic properties [90]-[92] and a regulatory role on drug resistance [93] [94].

The I.V administration of aminibisphosphonates monthly in the daily clinical practice has reduced skeletal related events at a remarkably lower level than before [95]. The optimal length they should be given is not fully determined yet but it is clear that treatment should continue for at least two years [96].

Risk of developing osteonecrosis of jaws and renal impairment are the most important clinical safety considerations [97]. In all patients creatinine clearance ( $\mathrm{CrCl})$, serum electrolytes, and urinary albuminmust be closely monitored [96] and careful dental evaluation is mandatory before aminibisphosphonates prescription [98]; Calcium and vitamin D3 supplementation can be used with caution to maintain calcium homeostasis.

Other antiresorptive therapies are emerging, inhibiting osteoclast function by affecting biological pathways that regulate osteoclasts' recruitment, activation, and function. The anti-Dkk-1 monoclonal antibody, denosumab is currently under evaluation in MM patients and has already proven its efficacy in postmenopausal osteoporosis [32]. Preliminary results are encouraging, while it also seems to confirm, in vivo, its potential pro-anabolic and anti-MM effect [99] [100]. Another antibody that was recently manufactured is romosozumab, an antibody against sclerostin, that in turn negatively regulates osteoblasts and inhibits bone formation; this drug (AMG 785) appears extremely potent [101].

\subsubsection{Emergency Treatment}

Spinal cord compression is an emergency situation. The usual primary management involves high-dose corticosteroids and radiation therapy. Surgical decompression may be considered as the choice to follow even though literature provides many controversial studies on when it is the appropriate time to proceed. Early studies on laminectomy had been abandoned as they did not present significant benefit over radiotherapy alone [102]. In a meta analysis study, Klimo et al. has presented the effectiveness of spinal decompression followed by immediate stabilization [103]. As most myelomatous lesions arise from the vertebral body, an anterior surgical approach is generally used, which may contribute to additional morbidity [71] but this is controversial and others support that direct decompressive surgery in combination with postoperative radiotherapy is superior to radiotherapy alone [104].

\section{Conclusion}

Multiple myeloma has the highest incidence of skeletal manifestations among malignant haematologic diseases. Albeit pain is the predesponsing symptom in approximately $60 \%$ of the symptomatic patients [4], spontaneous fractures, diffuse osteoporosis and spinal cord roots compression symptoms are additional clinical findings at diagnosis and throughout disease courses that lead to increased morbidity [1] [5]. Therapeutic strategy includes myeloma-directed chemotherapy, agents inhibiting bone resorption such as aminobisphosphonates and new promissing biology driven monoclonal antibodies targeting osteoclastogenesis mechanisms. Palliative MBD treatment includes analgesics, orthotics, radiation therapy, vertebroplasty and kyphoplasty. In case of spinal cord compression, radiation therapy or surgical decompression, should be instantly performed, along with steroid administration. Surgery may also be an option especially in case of weight-bearing bone fractures.

\section{References}

[1] Kyle, R.A., Gertz, M.A., Witzig, T.E., Lust, J.A., Lacy, M.Q., Dispenzieri, A., Fonseca, R., Rajkumar, S.V., Offord, J.R., Larson, D.R., Plevak, M.E., Therneau, T.M. and Greipp, P.R. (2003) Review of 1027 Patients with Newly Diagnosed Multiple Myeloma. Mayo Clinic Proceedings, 78, 21-33. http://dx.doi.org/10.4065/78.1.21

[2] Rajkumar, S.V. (2012) Multiple Myeloma: 2012 Update on Diagnosis, Risk-Stratification, and Management. American Journal of Hematology, 87, 452. http://dx.doi.org/10.1002/ajh.22237 
[3] Gay, F., Larocca, A., Wijermans, P., Cavallo, F., Rossi, D., Schaafsma, R., Genuardi, M., Romano, A., Liberati, A.M., Siniscalchi, A., Petrucci, M.T., Nozzoli, C., Patriarca, F., Offidani, M., Ria, R., Omedè, P., Bruno, B., Passera, R., Musto, P., Boccadoro, M., Sonneveld, P. and Palumbo, A. (2010) Complete Response Correlates with Long-Term Progression-Free and Overall Survival in Elderly Myeloma Treated with Novel Agents: Analysis of 1175 Patients. Blood, 117, 3025-3031. http://dx.doi.org/10.1182/blood-2010-09-307645

[4] Roodman, G.D. (2008) Skeletal Imaging and Management of Bone Disease. Hematology American Society of Hematology Education Program, 2008, 313-319.

[5] Kyle, R.A. (1975) Multiple Myeloma: Review of 869 Cases. Mayo Clinic Proceedings, 50, 29-40.

[6] Lentzsch, S., Ehrlich, L.A. and Roodman, G.D. (2007) Pathophysiology of Multiple Myeloma Bone Disease. Hematology/Oncology Clinics of North America, 21, 1035-1049. http://dx.doi.org/10.1016/j.hoc.2007.08.009

[7] Saad, F., Lipton, A., Cook, R., Chen, Y.-M., Smith, M. and Coleman, R. (2007) Pathologic Fractures Correlate with Reduced Survival in Patients with Malignant Bone Disease. Cancer, 110, 1860-1867.

http://dx.doi.org/10.1002/cncr.22991

[8] Chakraborti, C. and Miller, K.L. (2010) Multiple Myeloma Presenting as Spinal Cord Compression: A Case Report. Journal of Medical Case Reports, 4, 251. http://dx.doi.org/10.1186/1752-1947-4-251

[9] Durie, B.G. and Salmon, S. (1975) A Clinical Staging System for Multiple Myeloma. Correlation of Measured Myeloma Cell Mass with Presenting. Clinical Features, Response to Treatment, and Survival. Cancer, 36, 842-854. http://dx.doi.org/10.1002/1097-0142(197509)36:3<842::AID-CNCR2820360303>3.0.CO;2-U

[10] Li, S.D., Wang, Y.F., Qi, J.Y. and Qiu, L.G. (2010) Clinical Features of Bone Complications and Prognostic Value of Bone Lesions Detected by X-Ray Skeletal Survey in Previously Untreated Patients with Multiple Myeloma. Indian Journal of Hematology and Blood Transfusion, 26, 83-88. http://dx.doi.org/10.1007/s12288-010-0033-3

[11] Kyrtsonis, M.-C., Maltezas, D., Koulieris, E., Bitsani, K., Pessach, I., Efthymiou, A., Bartzis, V., Tzenou, T. and Panayiotidis, P. (2012) The Contribution of Prognostic Factors to the Better Management of Multiple Myeloma Patients. In: Multiple Myeloma-An Overview, InTech-Open Access Publisher, 145-174. http://dx.doi.org/10.5772/30425

[12] Pearse, R.N., Sordillo, E.M., Yaccoby, S., Wong, B.R., Liau, D.F., Colman, N., Michaeli, J., Epstein, J. and Choi, Y. (2001) Multiple Myeloma Disrupts the TRANCE/Osteoprotegerin Cytokine Axis to Trigger Bone Destruction and Promote Tumor Progression. Proceedings of the National Academy of Sciences of the United States of America, 98, 11581-11586. http://dx.doi.org/10.1073/pnas.201394498

[13] Barillé-Nion, S. and Bataille, R. (2003) New Insights in Myeloma-Induced Osteolysis. Leuk Lymphoma, 44, 14631467. http://dx.doi.org/10.1080/1042819031000082966

[14] Roux, S., Meignin, V., Quillard, J., Meduri, G., Guiochon-Mantel, A., Fermand, J.P., Milgrom, E. and Mariette, X. (2002) RANK (Receptor Activator of Nuclear Factor-KappaB) and RANKL Expression in Multiple Myeloma. British Journal of Haematology, 117, 86-92. http://dx.doi.org/10.1046/j.1365-2141.2002.03417.x

[15] Yasuda, H., Shima, N., Nakagawa, N., Yamaguchi, K., Kinosaki, M., Mochizuki, S., Tomoyasu, A., Yano, K., Goto, M., Murakami, A., Tsuda, E., Morinaga, T., Higashio, K., Udagawa, N., Takahashi, N. and Suda, T. (1998) Osteoclast Differentiation Factor Is a Ligand for Osteoprotegerin/Osteoclastogenesis-Inhibitory Factor and Is Identical to TRANCE/RANKL. Proceedings of the National Academy of Sciences of the United States of America, 95, 3597-3602. http://dx.doi.org/10.1073/pnas.95.7.3597

[16] Giuliani, N., Bataille, R., Mancini, C., Lazzaretti, M. and Barillé, S. (2001) Myeloma Cells Induce Imbalance in the Osteoprotegerin/Osteoprotegerin Ligand System in the Human Bone Marrow Environment. Blood, 98, 3527-3533. http://dx.doi.org/10.1182/blood.V98.13.3527

[17] Blair, J.M., Zhou, H., Seibel, M.J. and Dunstan, C.R. (2006) Mechanisms of Disease: Role of OPG, RANKL and RANK in the Pathophysiology of Skeletal Metastasis. Nature Clinical Practice Oncology, 3, 41-49. http://dx.doi.org/10.1038/ncponc0381

[18] Kelly, T., Suva, L.J., Nicks, K.M., MacLeod, V. and Sanderson, R.D. (2010) Tumor-Derived Syndecan-1 Mediates Distal Cross-Talk with Bone That Enhances Osteoclastogenesis. Journal of Bone and Mineral Research, 25, 12951304. http://dx.doi.org/10.1002/jbmr.16

[19] Seidel, C., Hjertner, Ø., Abildgaard, N., Heickendorff, L., Hjorth, M., Westin, J., Nielsen, J.L., Hjorth-Hansen, H., Waage, A., Sundan, A. and Børset, M., Nordic Myeloma Study Group (2001) Serum Osteoprotegerin Levels Are Reduced in Patients with Multiple Myeloma with Lytic Bone Disease. Blood, 98, 2269-2271. http://dx.doi.org/10.1182/blood.V98.7.2269

[20] Terpos, E., Szydlo, R., Apperley, J.F., Hatjiharissi, E., Politou, M., Meletis, J., Viniou, N., Yataganas, X., Goldman, J.M. and Rahemtulla, A. (2003) Soluble Receptor Activator of Nuclear Factor $\kappa$ B Ligand-Osteoprotegerin Ratio Predicts Survival in Multiple Myeloma: Proposal for a Novel Prognostic Index. Blood, 102, 1064-1069. http://dx.doi.org/10.1182/blood-2003-02-0380 
[21] Goranova-Marinova, V., Goranov, S., Pavlov, P. and Tzvetkova, T. (2007) Serum Levels of OPG, RANKL and RANKL/OPG Ratio in Newly-Diagnosed Patients with Multiple Myeloma. Clinical Correlations. Haematologica, 92, 1000-1001. http://dx.doi.org/10.3324/haematol.10943

[22] Martini, G., Gozzetti, A., Gennari, L., Avanzati, A., Nuti, R. and Lauria, F. (2006) The Effect of Zoledronic Acid on Serum Osteoprotegerin in Early Stage Multiple Myeloma. Haematologica, 91, 1720-1721.

[23] Terpos, E., Mihou, D., Szydlo, R., Tsimirika, K., Karkantaris, C., Politou, M., Voskaridou, E., Rahemtulla, A., Dimopoulos, M.A. and Zervas, K. (2005) The Combination of Intermediate Doses of Thalidomide with Dexamethasone Is an Effective Treatment for Patients with Refractory/Relapsed Multiple Myeloma and Normalizes Abnormal Bone Remodeling, through the Reduction of sRANKL/Osteoprotegerin Ratio. Leukemia, 19, 1969-1976. http://dx.doi.org/10.1038/sj.leu.2403890

[24] Kraj, M., Owczarska, K., Sokolowska, U., Centkowski, P., Poglod, R. and Kruk, B. (2005) Correlation of Osteoprotegerin and sRANKL Concentrations in Serum and Bone Marrow of Multiple Myeloma Patients. Archivum Immunologiae et Therapia Experimentalis, 53, 454-464.

[25] Depil, S., Mathiot, C., Leleu, X., Moreau, A.S., Faucompré, J.L., Hennache, B., Bauters, F., Bataille, R. and Facon, T. (2005) Evaluation and Prognostic Value of Serum Osteoprotegerin in Multiple Myeloma. British Journal of Haematology, 129, 706-707. http://dx.doi.org/10.1111/j.1365-2141.2005.05518.x

[26] Corso, A., Dovio, A., Rusconi, C., Sartori, M.L., Klersy, C., Varettoni, M., Mangiacavalli, S., Zappasodi, P., Ventura, M., Angeli, A. and Lazzarino, M. (2004) Osteoprotegerin Serum Levels in Multiple Myeloma and MGUS Patients Compared with Age- and Sex-Matched Healthy Controls. Leukemia, 18, 1555-1557. http://dx.doi.org/10.1038/sj.leu.2403429

[27] Kyrtsonis, M.C., Vassilakopoulos, T.P., Siakantaris, M.P., Kokoris, S.I., Gribabis, D.A., Dimopoulou, M.N., Angelopoulou, M.K. and Pangalis, G.A. (2004) Serum Syndecan-1, Basic Fibroblast Growth Factor and Osteoprotegerin in Myeloma Patients at Diagnosis and during the Course of the Disease. European Journal of Haematology, 72, 252-258. http://dx.doi.org/10.1046/j.0902-4441.2003.00205.x

[28] Terpos, E., Politou, M., Szydlo, R., Nadal, E., Avery, S., Olavarria, E., Kanfer, E., Goldman, J.M., Apperley, J.F. and Rahemtulla, A. (2004) Autologous Stem Cell Transplantation Normalizes Abnormal Bone Remodeling and sRANKL/ Osteoprotegerin Ratio in Patients with Multiple Myeloma. Leukemia, 18, 1420-1426. http://dx.doi.org/10.1038/sj.leu.2403423

[29] Seidel, C., Hjertner, Ø., Abildgaard, N., Heickendorff, L., Hjorth, M., Westin, J., Nielsen, J.L., Hjorth-Hansen, H., Waage, A., Sundan, A. and Børset, M., Nordic Myeloma Study Group (2001) Serum Osteoprotegerin Levels Are Reduced in Patients with Multiple Myeloma with Lytic Bone Disease. Blood, 98, 2269-2271. http://dx.doi.org/10.1182/blood.V98.7.2269

[30] Bekker, P.J., Holloway, D., Nakanishi, A., Arrighi, M., Leese, P.T. and Dunstan, C.R. (2001) The Effect of a Single Dose of Osteoprotegerin in Postmenopausal Women. Journal of Bone and Mineral Research, 16, 348-360. http://dx.doi.org/10.1359/jbmr.2001.16.2.348

[31] Body, J.J., Greipp, P., Coleman, R.E., Facon, T., Geurs, F., Fermand, J.P., Harousseau, J.L., Lipton, A., Mariette, X., Williams, C.D., Nakanishi, A., Holloway, D., Martin, S.W., Dunstan, C.R. and Bekker, P.J. (2003) A Phase I Study of AMGN-0007, a Recombinant Osteoprotegerin Construct, in Patients with Multiple Myeloma or Breast Carcinoma Related Bone Metastases. Cancer, 97, 887-892. http://dx.doi.org/10.1002/cncr.11138

[32] Charopoulos, I., Orme, S. and Giannoudis, P.V. (2011) The Role and Efficacy of Denosumab in the Treatment of Osteoporosis: An Update. Expert Opinion on Drug Safety, 10, 205-217. http://dx.doi.org/10.1517/14740338.2010.516249

[33] Qiang, Y.W., Chen, Y., Stephens, O., Brown, N., Chen, B., Epstein, J., Barlogie, B. and Shaughnessy Jr., J.D. (2008) Myeloma-Derived Dickkopf-1 Disrupts Wnt-Regulated Osteoprotegerin and RANKL Production by Osteoblasts: A Potential Mechanism Underlying Osteolytic Bone Lesions in Multiple Myeloma. Blood, 112, 196-207. http://dx.doi.org/10.1182/blood-2008-01-132134

[34] Edwards, C.M., Edwards, J.R., Lwin, S.T., Esparza, J., Oyajobi, B.O., McCluskey, B., Munoz, S., Grubbs, B. and Mundy, G.R. (2008) Increasing Wnt Signaling in the Bone Marrow Microenvironment Inhibits the Development of Myeloma Bone Disease and Reduces Tumor Burden in Bone in Vivo. Blood, 111, 2833-2842. http://dx.doi.org/10.1182/blood-2007-03-077685

[35] Tian, E., Zhan, F., Walker, R., Rasmussen, E., Ma, Y., Barlogie, B., Shaughnessy Jr., J.D. (2003) The Role of the Wnt-Signaling Antagonist DKK1 in the Development of Osteolytic Lesions in Multiple Myeloma. The New England Journal of Medicine, 349, 2483-2494. http://dx.doi.org/10.1056/NEJMoa030847

[36] Li, J., Sarosi, I., Cattley, R.C., Pretorius, J., Asuncion, F., Grisanti, M., Morony, S., Adamu, S., Geng, Z., Qiu, W., Kostenuik, P., Lacey, D.L., Simonet, W.S., Bolon, B., Qian, X., Shalhoub, V., Ominsky, M.S., Ke, H.Z., Li, X. and Richards, W.G. (2006) Dkk1-Mediated Inhibition of Wnt Signaling in Bone Results in Osteopenia. Bone, 39, 754-766. http://dx.doi.org/10.1016/j.bone.2006.03.017 
[37] Morvan, F., Boulukos, K., Clément-Lacroix, P., Roman Roman, S., Suc-Royer, I., Vayssière, B., Ammann, P., Martin, P., Pinho, S., Pognonec, P., Mollat, P., Niehrs, C., Baron, R. and Rawadi, G. (2006) Deletion of a Single Allele of the Dkk1 Gene Leads to an Increase in Bone Formation and Bone Mass. Journal of Bone and Mineral Research, 21, 934945. http://dx.doi.org/10.1359/jbmr.060311

[38] Politou, M.C., Heath, D.J., Rahemtulla, A., Szydlo, R., Anagnostopoulos, A., Dimopoulos, M.A., Croucher, P.I. and Terpos, E. (2006) Serum Concentrations of Dickkopf-1 Protein Are Increased in Patients with Multiple Myeloma and Reduced after Autologous Stem Cell Transplantation. International Journal of Cancer, 119, 1728-1731. http://dx.doi.org/10.1002/ijc.22033

[39] Kaiser, M., Mieth, M., Liebisch, P., Oberländer, R., Rademacher, J., Jakob, C., Kleeberg, L., Fleissner, C., Braendle, E., Peters, M., Stover, D., Sezer, O. and Heider, U. (2008) Serum Concentrations of DKK-1 Correlate with the Extent of Bone Disease in Patients with Multiple Myeloma. European Journal of Haematology, 80, 490-494. http://dx.doi.org/10.1111/j.1600-0609.2008.01065.x

[40] Stavropoulos, N., Maltezas, D., Koulieris, E., Tzenou, T., Bartzis, V., Georgiou, G., Dimou, M., Papanikolaou, X., Repousis, P., Panagiotidis, P. and Kyrtsonis, M.-C. (2011) Dickkopf-1 Protein (Dkk1) Concentration in Serum at Diagnosis Is Strongly Correlated to Fractures in Patients with Multiple Myeloma (MM). Proceedings of Conference 13th International Myeloma Workshop on Haematologica, 130.

[41] Edwards, C.M. and Mundy, G.R. (2010) Proteasome Inhibitors and the Wnt Signaling Pathway in Myeloma Bone Disease. In: Roodman, G.D., Ed., Myeloma Bone Disease, Chap. 12, Humana Press, Springer, New York Dordrecht Heidelberg London, 211-229. http://dx.doi.org/10.1007/978-1-60761-554-5_12

[42] Lentzsch, S., Gries, M., Janz, M., Bargou, R., Dörken, B. and Mapara, M.Y. (2003) Macrophage Inflammatory Protein 1-Alpha (MIP-1 $\alpha$ ) Triggers Migration and Signaling Cascades Mediating Survival and Proliferation in Multiple Myeloma (MM) Cells. Blood, 101, 3568-3573. http://dx.doi.org/10.1182/blood-2002-08-2383

[43] Menu, E., De Leenheer, E., De Raeve, H., Coulton, L., Imanishi, T., Miyashita, K., Van Valckenborgh, E., Van Riet, I., Van Camp, B., Horuk, R., Croucher, P. and Vanderkerken, K. (2006) Role of CCR1 and CCR5 in Homing and Growth of Multiple Myeloma and in the Development of Osteolytic Lesions: A Study in the 5TMM Model. Clinical and Experimental Metastasis, 23, 291-300. http://dx.doi.org/10.1007/s10585-006-9038-6

[44] Abe, M., Hiura, K., Wilde, J., Moriyama, K., Hashimoto, T., Ozaki, S., Wakatsuki, S., Kosaka, M., Kido, S., Inoue, D. and Matsumoto, T. (2002) Role for Macrophage Inflammatory Protein (MIP)-1Alpha and MIP-1Beta in the Development of Osteolytic Lesions in Multiple Myeloma. Blood, 100, 2195-2202.

[45] Hata, H. (2005) Bone Lesions and Macrophage Inflammatory Protein-1 Alpha (MIP-1 $\alpha$ ) in Human Multiple Myeloma. Leukemia \& Lymphoma, 46, 967-972. http://dx.doi.org/10.1080/10428190500066636

[46] Oba, Y., Lee, J.W., Ehrlich, L.A., Chung, H.Y., Jelinek, D.F., Callander, N.S., Horuk, R., Choi, S.J. and Roodman, G.D. (2005) MIP-1Alpha Utilizes Both CCR1 and CCR5 to Induce Osteoclast Formation and Increase Adhesion of Myeloma Cells to Marrow Stromal Cells. Experimental Hematology, 33, 272-278. http://dx.doi.org/10.1016/j.exphem.2004.11.015

[47] Han, J.H., Choi, S.J., Kurihara, N., Koide, M., Oba, Y. and Roodman, G.D. (2001) Macrophage Inflammatory Protein-1Alpha Is an Osteoclastogenic Factor in Myeloma That Is Independent of Receptor Activator of Nuclear Factor Kappab Ligand. Blood, 97, 3349-3353. http://dx.doi.org/10.1182/blood.V97.11.3349

[48] Terpos, E., Politou, M., Szydlo, R., Goldman, J.M., Apperley, J.F. and Rahemtulla, A. (2003) Serum Levels of Macrophage Inflammatory Protein-1 Alpha (MIP-1 Alpha) Correlate with the Extent of Bone Disease and Survival in Patients with Multiple Myeloma. British Journal of Haematology, 123, 106-109. http://dx.doi.org/10.1046/j.1365-2141.2003.04561.x

[49] Terpos, E., Politou, M., Viniou, N. and Rahemtulla, A. (2005) Significance of Macrophage Inflammatory Protein-1 Alpha (MIP-1 $\alpha$ ) in Multiple Myeloma. Leukemia \& Lymphoma, 46, 1699-1707. http://dx.doi.org/10.1080/10428190500175049

[50] Papadogiannis, A., Kyrtsonis, M.-C., Vassilakopoulos, T.P., Tzenou, T., Antoniadis, A.G., Kalpadakis, C., Sachanas, S., Dimopoulou, M.N., Siakantaris, M.P., Kokoris, S.I., Dimitriadou, E.M., Angelopoulou, M.K., Plata, E., Tsaftaridis, P. and Pangalis, G. (2005) Serum Levels of OPG and MIP-1 $\alpha$ in Untreated Multiple Myeloma Patients. Correlations with Staging, Survival and Bone Disease. Blood, 106, Abstract 5074.

[51] Vanderkerken, K., Asosingh, K., Braet, F., Van Riet, I. and Van Camp, B. (1999) Insulin-Like Growth Factor-1 Acts as a Chemoattractant Factor for 5T2 Multiple Myeloma Cells. Blood, 93, 235-241.

[52] Ge, N.L. and Rudikoff, S. (2000) Insulin-Like Growth Factor I Is a Dual Effector of Multiple Myeloma Cell Growth. Blood, 96, 2856-2861.

[53] Mitsiades, C.S., Mitsiades, N.S., McMullan, C.J., Poulaki, V., Shringarpure, R., Akiyama, M., Hideshima, T., Chauhan, D., Joseph, M., Libermann, T.A., García-Echeverría, C., Pearson, M.A., Hofmann, F., Anderson, K.C. and Kung, A.L. (2004) Inhibition of the Insulin-Like Growth Factor Receptor-1 Tyrosine Kinase Activity as a Therapeutic Strategy for 
Multiple Myeloma, Other Hematologic Malignancies, and Solid Tumors. Cancer Cell, 5, 221-230. http://dx.doi.org/10.1016/S1535-6108(04)00050-9

[54] Georgii-Hemming, P., Wiklund, H.J., Ljunggren, O. and Nilsson, K. (1996) Insulin-Like Growth Factor I Is a Growth and Survival Factor in Human Multiple Myeloma Cell Lines. Blood, 88, 2250-2258.

[55] Abboud, S.L., Bethel, C.R. and Aron, D.C. (1991) Secretion of Insulin-Like Growth Factor I and Insulinlike Growth Factor-Binding Proteins by Murine Bone Marrow Stromal Cells. Journal of Clinical Investigation, 88, 470-475. http://dx.doi.org/10.1172/JCI115327

[56] Middleton, J., Arnott, N., Walsh, S. and Beresford, J. (1995) Osteoblasts and Osteoclasts in Adult Human Osteophyte Tissue Express the mRNAs for Insulin-Like Growth Factor I and II and the Type I IGF Receptor. Bone, 16, 287-293. http://dx.doi.org/10.1016/8756-3282(94)00040-9

[57] Freund, G.G., Kulas, D.T., Way, B.A. and Mooney, R.A. (1994) Functional Insulin and Insulin-Like Growth Factor-1 Receptors Are Preferentially Expressed in Multiple Myeloma Cell Lines as Compared to B-Lymphoblastoid Cell Lines. Cancer Research, 54, 3179-3185.

[58] Jelinek, D.F., Witzig, T.E. and Arendt, B.K. (1997) A Role for Insulin-Like Growth Factor in the Regulation of IL-6-Responsive Human Myeloma Cell Line Growth. Journal of Immunology, 159, 487-496.

[59] Abroun, S., Ishikawa, H., Tsuyama, N., Liu, S., Li, F.J., Otsuyama, K., Zheng, X., Obata, M. and Kawano, M.M. (2004) Receptor Synergy of Interleukin-6 (IL-6) and Insulin-Like Growth Factor-I That Highly Express IL-6 Receptor $\alpha$ Myeloma Cells. Blood, 103, 2291-2298. http://dx.doi.org/10.1182/blood-2003-07-2187

[60] Ferlin, M., Noraz, N., Hertogh, C., Brochier, J., Taylor, N. and Klein, B. (2000) Insulin-Like Growth Factor Induces the Survival and Proliferation of Myeloma Cells through an Interleukin-6-Independent Transduction Pathway. British Journal of Haematology, 111, 626-634. http://dx.doi.org/10.1046/j.1365-2141.2000.02364.x

[61] Tu, Y., Gardner, A. and Lichtenstein, A. (2000) The Phosphatidylinositol 3-Kinase/AKT kinase Pathway in Multiple Myeloma Plasma Cells: Roles in Cytokine-Dependent Survival and Proliferative Responses. Cancer Research, 60, 6763-6770.

[62] Qiang, Y.W., Kopantzev, E. and Rudikoff, S. (2002) Insulin-Like Growth Factor-I Signaling in Multiple Myeloma: Downstream Elements, Functional Correlates, and Pathway Cross-Talk. Blood, 11, 4138-4146. http://dx.doi.org/10.1182/blood.V99.11.4138

[63] Pollak, M. (2008) Insulin and Insulin-Like Growth Factor Signalling in Neoplasia. Nature Reviews Cancer, 8, 915-928. http://dx.doi.org/10.1038/nrc2536

[64] Melton 3rd, L.J., Rajkumar, S.V., Khosla, S., Achenbach, S.J., Oberg, A.L. and Kyle, R.A. (2004) Fracture Risk in Monoclonal Gammopathy of Undetermined Significance. Journal of Bone and Mineral Research, 19, 25-30. http://dx.doi.org/10.1359/jbmr.0301212

[65] Kumar, S.K., Rajkumar, S.V., Dispenzieri, A., Lacy, M.Q., Hayman, S.R., Buadi, F.K., Zeldenrust, S.R., Dingli, D., Russell, S.J., Lust, J.A., Greipp, P.R., Kyle, R.A. and Gertz, M.A. (2008) Improved Survival in Multiple Myeloma and the Impact of Novel Therapies. Blood, 111, 2516-2520. http://dx.doi.org/10.1182/blood-2007-10-116129

[66] Lonial, S. (2010) Presentation and Risk Stratification-Improving Prognosis for Patients with Multiple Myeloma. Cancer Treatment Reviews, 36, 12-17. http://dx.doi.org/10.1016/S0305-7372(10)70007-4

[67] Terpos, E., Heath, D.J., Rahemtulla, A., Zervas, K., Chantry, A., Anagnostopoulos, A., Pouli, A., Katodritou, E., Verrou, E., Vervessou, E.C., Dimopoulos, M.A. and Croucher, P.I. (2006) Bortezomib Reduces Serum Dickkopf-1 and Receptor Activator of Nuclear Factor-KappaB Ligand Concentrations and Normalises Indices of Bone Remodelling in Patients with Relapsed Multiple Myeloma. British Journal of Haematology, 135, 688-692. http://dx.doi.org/10.1111/j.1365-2141.2006.06356.x

[68] Terpos, E., Christoulas, D., Kastritis, E., Katodritou, E., Papatheodorou, A., Pouli, A., Kyrtsonis, M.C., Michalis, E., Papanikolaou, X., Gkotzamanidou, M., Koulieris, E., Gavriatopoulou, M., Zervas, K. and Dimopoulos, M.A., on behalf of the Greek Myeloma Study Group (2014) The Combination of Lenalidomide and Dexamethasone Reduces Bone Resorption in Responding Patients with Relapsed/Refractory Multiple Myeloma but Has No Effect on Bone Formation: Final Results on 205 Patients of the Greek Myeloma Study Group. American Journal of Hematology, 89, 34-40.

[69] Greenberger, J.S. (2010) Radiation Therapy in Multiple Myeloma. In: Roodman, G.D., Ed., Myeloma Bone Disease, Chap. 4, Humana Press, Springer, New York Dordrecht Heidelberg London, 91-100. http://dx.doi.org/10.1007/978-1-60761-554-5_4

[70] DeVita, V., Hellman, S. and Rosenberg, S. (2005) Cancer, Principles and Practice of Oncology. In: DePinho, R. and Weimberg, R., Eds., Cancer, Principles and Practice of Oncology, Lippincott Williams and Wilkins, Philadelphia.

[71] George, R., Jeba, J., Ramkumar, G., Chacko, A.G., Leng, M. and Tharyan, P. (2008) Interventions for the Treatment of Metastatic Extradural Spinal Cord Compression in Adults. The Cochrane Database of Systematic Reviews, No. 4, CD006716. 
[72] Hussein, M. (2010) Surgical Management of Bone Disease. In: Roodman, G.D., Ed., Myeloma Bone Disease, Chap. 5, Humana Press, Springer, New York Dordrecht Heidelberg London, 101-116. http://dx.doi.org/10.1007/978-1-60761-554-5_5

[73] Fourney, D.R., Schomer, D.F., Nader, R., Chlan-Fourney, J., Suki, D., Ahrar, K., Rhines, L.D. and Gokaslan, Z.L. (2003) Percutaneous Vertebroplasty and Kyphoplasty for Painful Vertebral Body Fractures in Cancer Patients. Journal of Neurosurgery, 98, 21-30.

[74] Papadopoulos, E.C., Edobor-Osula, F., Gardner, M.J., Shindle, M.K. and Lane, J.M. (2008) Unipedicular Balloon Kyphoplasty for the Treatment of Osteoporotic Vertebral Compression Fractures: Early Results. Journal of Spinal Disorders \& Techniques, 21, 589-596. http://dx.doi.org/10.1097/BSD.0b013e31815d6997

[75] Malempati, H., Qamirani, E. and Yee, A.J.M. (2012) Metastatic/Myeloma Disease-Operative Management. In: Evidence Based Orthopaedics, Wiley-Blackwell, BMJ Books, 721-727. http://www.evidencebasedseries.com

[76] Hussein, M.A., Vrionis, F.D., Allison, R., Berenson, J., Berven, S., Erdem, E., Giralt, S., Jagannath, S., Kyle, R.A., LeGrand, S., Pflugmacher, R., Raje, N., Rajkumar, S.V., Randall, R.L., Roodman, D., Siegel, D., Vescio, R., Zonder, J. and Durie, B.G., International Myeloma Working Group (2008) The Role of Vertebral Augmentation in Multiple Myeloma: International Myeloma Working Group Consensus Statement. Leukemia, 22, 1479-1484. http://dx.doi.org/10.1038/leu.2008.127

[77] Harrington, K.D. (1986) Impending Pathologic Fractures from Metastatic Malignancy: Evaluation and Management. Instructional Course Lectures, 35, 357-381.

[78] Mirels, H. (1989) Metastatic Disease in Long Bones: A Proposed Scoring System for Diagnosing Impending Pathologic Fractures. Clinical Orthopaedics and Related Research, 249, 256-264.

[79] Papagelopoulos, P.J., Galanis, E.C., Greipp, P.R. and Sim, F.H. (1997) Prosthetic Hip Replacement for Pathologic or Impending Pathologic Fractures in Myeloma. Clinical Orthopaedics and Related Research, 341, 192-205. http://dx.doi.org/10.1097/00003086-199708000-00029

[80] Allan, D.G., Bell, R.S., Davis, A. and Langer, F. (1995) Complex Acetabular Reconstruction for Metastatic Tumor. The Journal of Arthroplasty, 10, 301-306. http://dx.doi.org/10.1016/S0883-5403(05)80178-0

[81] Benevenia, J., Cyran, F.P., Biermann, J.S., Patterson, F.R. and Leeson, M.C. (2004) Treatment of Advanced Metastatic Lesions of the Acetabulum Using the Saddle Prosthesis. Clinical Orthopaedics and Related Research, 426, $23-31$. http://dx.doi.org/10.1097/01.blo.0000141387.03035.3e

[82] Stark, A. and Nauer, H.C. (1996) Reconstruction in Metastatic Destruction of the Acetabulum: Support Rings and Arthroplasty in 12 Patients. Acta Orthopaedica, 67, 435-438. http://dx.doi.org/10.3109/17453679608996663

[83] Coleman, R.E. (2004) Bisphosphonates: Clinical Experience. The Oncologist, 9, 14-27. http://dx.doi.org/10.1634/theoncologist.9-90004-14

[84] Baulch-Brown, C., Molloy, T.J., Yeh, S.L., Ma, D. and Spencer, A. (2007) Inhibitors of the Mevalonate Pathway as Potential Therapeutic Agents in Multiple Myeloma. Leukemia Research, 31, 341-352. http://dx.doi.org/10.1016/j.leukres.2006.07.018

[85] Shipman, C.M., Rogers, M.J., Apperley, J.F., Russell, R.G. and Croucher, P.I. (1997) Bisphosphonates Induce Apoptosis in Human Myeloma Cell Lines: A Novel Anti-Tumour Activity. British Journal of Haematology, 98, 665-672. http://dx.doi.org/10.1046/j.1365-2141.1997.2713086.x

[86] Tassone, P., Forciniti, S., Galea, E., Morrone, G., Turco, M.C., Martinelli, V., Tagliaferri, P. and Venuta, S. (2000) Growth Inhibition and Synergistic Induction of Apoptosis by Zoledronate and Dexamethasone in Human Myeloma Cell Lines. Leukemia, 14, 841-844. http://dx.doi.org/10.1038/sj.leu.2401770

[87] Ural, A.U., Yilmaz, M.I., Avcu, F., Pekel, A., Zerman, M., Nevruz, O., Sengul, A. and Yalcin, A. (2003) The Bisphosphonate Zoledronic Acid Induces Cytotoxicity in Human Myeloma Cell Lines with Enhancing Effects of Dexamethasone and Thalidomide. International Journal of Hematology, 78, 443-449. http://dx.doi.org/10.1007/BF02983818

[88] Corso, A., Ferretti, E., Lunghi, M., Zappasodi, P., Mangiacavalli, S., De Amici, M., Rusconi, C., Varettoni, M. and Lazzarino, M. (2005) Zoledronic Acid Down-Regulates Adhesion Molecules of Bone Marrow Stromal Cells in Multiple Myeloma: A Possible Mechanism for Its Antitumor Effect. Cancer, 104, 118-125. http://dx.doi.org/10.1002/cncr.21104

[89] Zwolak, P., Manivel, J.C., Jasinski, P., Kirstein, M.N., Dudek, A.Z., Fisher, J. and Cheng, E.Y. (2010) Cytotoxic Effect of Zoledronic Acid-Loaded Bone Cement on Giant Cell Tumor, Multiple Myeloma, and Renal Cell Carcinoma Cell Lines. The Journal of Bone \& Joint Surgery, 92, 162-168. http://dx.doi.org/10.2106/JBJS.H.01679

[90] Uchida, R., Ashihara, E., Sato, K., Kimura, S., Kuroda, J., Takeuchi, M., Kawata, E., Taniguchi, K., Okamoto, M., Shimura, K., Kiyono, Y., Shimazaki, C., Taniwaki, M. and Maekawa, T. (2007) Gamma Delta T Cells Kill Myeloma Cells by Sensing Mevalonate Metabolites and ICAM-1 Molecules on Cell Surface. Biochemical and Biophysical Re- 
search Communications, 354, 613-618. http://dx.doi.org/10.1016/j.bbrc.2007.01.031

[91] Kunzmann, V., Bauer, E., Feurle, J., Weissinger, F., Tony, H.P. and Wilhelm, M. (2000) Stimulation of $\gamma \delta$ Cells by Aminobisphosphonates and Induction of Antiplasma Cell Activity in Multiple Myeloma. Blood, 96, 384-392.

[92] Moschetta, M., Di Pietro, G., Ria, R., Gnoni, A., Mangialardi, G., Guarini, A., Ditonno, P., Musto, P., D’Auria, F., Ricciardi, M.R., Dammacco, F., Ribatti, D. and Vacca, A. (2010) Bortezomib and Zoledronic acid on Angiogenic and Vasculogenic Activities of Bone Marrow Macrophages in Patients with Multiple Myeloma. European Journal of Cancer, 46, 420-429. http://dx.doi.org/10.1016/j.ejca.2009.10.019

[93] Schmidmaier, R., Simsek, M., Baumann, P., Emmerich, B. and Meinhardt, G. (2006) Synergistic Antimyeloma Effects of Zoledronate and Simvastatin. Anti-Cancer Drugs, 17, 621-619. http://dx.doi.org/10.1097/01.cad.0000215058.85813.02

[94] Koizumi, M., Nakaseko, C., Ohwada, C., Takeuchi, M., Ozawa, S., Shimizu, N., Cho, R., Nishimura, M. and Saito, Y. (2007) Zoledronate Has an Antitumor Effect and Induces Actin Rearrangement in Dexamethasone-Resistant Myeloma Cells. European Journal of Haematology, 79, 382-391. http://dx.doi.org/10.1111/j.1600-0609.2007.00957.X

[95] Lacy, M.Q., Dispenzieri, A., Gertz, M.A., Greipp, P.R., Gollbach, K.L., Hayman, S.R., Kumar, S., Lust, J.A., Rajkumar, S.V., Russell, S.J., Witzig, T.E., Zeldenrust, S.R., Dingli, D., Bergsagel, P.L., Fonseca, R., Reeder, C.B., Stewart, A.K., Roy, V., Dalton, R.J., Carr, A.B., Kademani, D., Keller, E.E., Viozzi, C.F. and Kyle, R.A. (2006) Mayo Clinic Consensus Statement for the Use of Bisphosphonates in Multiple Myeloma. Mayo Clinic Proceedings, 81, 1047-1053. http://dx.doi.org/10.4065/81.8.1047

[96] Terpos, E., Morgan, G., Dimopoulos, M.A., Drake, M.T., Lentzsch, S., Raje, N., Sezer, O., García-Sanz, R., Shimizu, K., Turesson, I., Reiman, T., Jurczyszyn, A., Merlini, G., Spencer, A., Leleu, X., Cavo, M., Munshi, N., Rajkumar, S.V., Durie, B.G. and Roodman, G.D. (2013) International Myeloma Working Group Recommendations for the Treatment of Multiple Myeloma-Related Bone Disease. Journal of Clinical Oncology, 31, 2347-2357.

[97] Terpos, E., Dimopoulos, M.A. and Berenson, J. (2011) Established Role of Bisphosphonate Therapy for Prevention of Skeletal Complications from Myeloma Bone Disease. Critical Reviews in Oncology/Hematology, 77, 13-23. http://dx.doi.org/10.1016/S1040-8428(11)70004-X

[98] Nicolatou-Galitis, O., Papadopoulou, E., Sarri, T., Boziari, P., Karayianni, A., Kyrtsonis, M.C., Repousis, P., Barbounis, V. and Migliorati, C.A. (2011) Osteonecrosis of the Jaw in Oncology Patients Treated with Bisphosphonates: Prospective Experience of a Dental Oncology Referral Center. Oral Surgery, Oral Medicine, Oral Pathology, Oral Radiology, and Endodontology, 112, 195-202. http://dx.doi.org/10.1016/j.tripleo.2011.02.037

[99] Pozzi, S., Fulciniti, M., Yan, H., Vallet, S., Eda, H., Patel, K., Santo, L., Cirstea, D., Hideshima, T., Schirtzinge, L., Kuhstoss, S., Anderson, K.C., Munshi, N., Scadden, D., Kronenberg, H.M. and Raje, N. (2013) In Vivo and in Vitro Effects of a Novel Anti-Dkk1 Neutralizing Antibody in Multiple Myeloma. Bone, 53, 487-496. http://dx.doi.org/10.1016/j.bone.2013.01.012

[100] Fulciniti, M., Tassone, P., Hideshima, T., Vallet, S., Nanjappa, P., Ettenberg, S.A., Shen, Z., Patel, N., Tai, Y.T., Chauhan, D., Mitsiades, C., Prabhala, R., Raje, N., Anderson, K.C., Stover, D.R. and Munshi, N.C. (2009) Anti-DKK1 mAb (BHQ880) as a Potential Therapeutic Agent for Multiple Myeloma. Blood, 114, 371-379. http://dx.doi.org/10.1182/blood-2008-11-191577

[101] Padhi, D., Jang, G., Stouch, B., Fang, L. and Posvar, E. (2011) Single-Dose, Placebo-Controlled, Randomized Study of AMG 785, a Sclerostin Monoclonal Antibody. Journal of Bone and Mineral Research, 26, 19-26. http://dx.doi.org/10.1002/jbmr.173

[102] Young, R.F., Post, E.M. and King, G.A. (1980) Treatment of Spinal Epidural Metastases. Randomized Prospective Comparison of Laminectomy and Radiotherapy. Journal of Neurosurgery, 53, 741-748. http://dx.doi.org/10.3171/jns.1980.53.6.0741

[103] Klimo Jr., P., Thompson, C.J., Kestle, J.R. and Schmidt, M.H. (2005) A Meta-Analysis of Surgery versus Conventional Radiotherapy for the Treatment of Metastatic Spinal Epidural Disease. Neuro-Oncology, 7, 64-76. http://dx.doi.org/10.1215/S1152851704000262

[104] Patchell, R.A., Tibbs, P.A., Regine, W.F., Payne, R., Saris, S., Kryscio, R.J., Mohiuddin, M. and Young, B. (2005) Direct Decompressive Surgical Resection in the Treatment of Spinal Cord Compression Caused by Metastatic Cancer: A Randomised Trial. Lancet, 366, 643-648. http://dx.doi.org/10.1016/S0140-6736(05)66954-1 